\title{
PEMBINAAN MASYARAKAT USIA LANJUT MELALUI PEMERIKSAAN DAN PENYULUHAN KESEHATAN, SERTA MENGAJARKAN SENAM ANTIHIPERTENSI DI POSYANDU LANSIA DI WILAYAH KERJA PUSKESMAS PASUNDAN KELURAHAN JAWA SAMARINDA - KALIMANTAN TIMUR
}

\author{
${ }^{1}$ Yovita Erin, ${ }^{2}$ Samariah Yani \\ ${ }^{1,2}$ Prodi Keperawatan, STIKES Dirgahayu Samarinda \\ Jl. Pasundan No 54 telp, Fax (0541) 748335 \\ Yovitaerin9@gmail.com
}

\begin{abstract}
ABSTRAK
Di Asia beban hipertensi sangat tinggi, hal itu terbukti dengan meningkatnya angka kematian akibat penyakit kardiovaskular di beberapa negara, bersamaan dengan rendahnya tingkat pengendalian dan kesadaran penyakit. Data di Puskesmas Pasundan cakupan penderita hipertensi khususnya di kelurahan Jawa sebesar 3.413 penderita, namun capaian penderita hipertensi periode bulan Januari sampai dengan Apri 2018 adalah 426 penderita (12,48\%). Kegiatan pembinaan Lansia meliputi pemeriksaan tekanan darah, penyuluhan dan mengajarkan kepada para Lansia senam Antihipertensi. Berdasarkan pemeriksaan Tekanan darah diperoleh hasil bahwa: Tekanan darah Normal 32\%, Prehipertensi 29\%, Hipertansi Tahap satu $29 \%$ dan Hipertensi tahap dua sebesar $10 \%$, sedangkan untuk pemeriksaan gula darah $(>200 \mathrm{mg} / \mathrm{dl})$ sebanyak 71\%. Penyakit hipertensi merupakan penyakit tidak menular, tetapi merupakan penyakit sebagai akibat dari proses degenerative dan pola hidup yang tidak sehat, semakin tahun meningkat dengan resiko komplikasi yang bervariasi dari ringan sampai berat. Meningkatkan upaya Promotif dan Preventif sehingga para Lansia memiliki pengetahuan dan kesadaran untuk mencegah terjadinya komplikasi.
\end{abstract}

\section{Kata Kunci : Pemeriksaan, Penyuluhan kesehatan, dan Mengajarkan senam antihipertensi}

\section{Abstract}

The burden of hypertension is very high In Asia, this is evidenced by the increased mortality due to cardiovascular disease in several countries, together with the low level of control and awareness of the disease. Data in Puskesmas Pasundan coverage of hypertensive patients, especially in the Java village of 3,413 patients, but the achievements of hypertensive patients in the period from January to April 2018 was 426 patients $(12.48 \%)$. Elderly coaching activities include checking blood pressure, counseling and teaching the elderly Antihypertensive gymnastics. Based on blood pressure examination results showed that: 32\% Normal Blood Pressure, 29\% Prehypertension, 29\% Stage One Hypertension and Stage Two Hypertension by $10 \%$, while for blood sugar testing $(>200 \mathrm{mg} / \mathrm{dl})$ as much as $71 \%$. Hypertension is a non-communicable disease, but it is a disease as a result of degenerative processes and unhealthy lifestyles, increasing with the risk of complications that vary from mild to severe. Increasing Promotive and Preventive efforts so that the Elderly have the knowledge and awareness to prevent complications

Keywords: Examination, health education, and teach antihypertensive exercises 


\section{PENDAHULUAN}

Di Asia beban hipertensi sangat tinggi, hal itu terbukti dengan meningkatnya angka kematian akibat penyakit kardiovaskular di beberapa negara, bersamaan dengan rendahnya tingkat pengendalian dan kesadaran penyakit.

Dr. dr. Yuda Turana SpS, Ketua InaSH dalam Press Conferencence The $12^{\text {th }}$ Annual Scientific Meeting of Indonesian Society of Hypertension (InaSH) bertema The Neverending Battle Against Hypertension and Itís Complications menyampaikan penelitian yang dilakukan Kemenkes RI, menunjukkan bahwa prevalensi hipertensi memiliki kisaran yang tidak berubah, yaitu $31,7 \%$ pada data RKD 2007 dan 32,4\% pada data Survei Indikator Kesehatan Nasional 2016. Hal ini menunjukkan bahwa prevalensi penyakit ini cenderung tidak menurun, bahkan ada tren yang meningkat karena data prevalensi pada Riskesdas 2013 menunjukkan prevalensi sebesar 26,5\%.

Berdasarkan data yang diperoleh dari Puskesmas Pasundan cakupan penderita hipertensi khususnya di kelurahan Jawa sebesar 3.413 penderita, namun capaian penderita hipertensi periode bulan Januari sampai dengan Apri 2018 baru mencapai 426 penderita dengan prosentase 12,48 . Hipertensi sebagai salah satu faktor risiko penyakit kardiovaskular, dr Arieska Ann Soenarta SpJP FIHA FasCC menjelaskan, 30\% kematian di dunia disebabkan adanya kelainan kardiovaskuler. Lebih lanjut dr. Arieska menjelaskan faktor risiko yang menyebabkan kelainan kardiovaskuler ada banyak dan akan semakin bertambah. Dan dari seluruh faktor risiko, hipertensi menduduki peringkat teratas.

Pada pasien hipertensi, jantung dapat mengalami pembengkakan saat tekanan darah pasien tinggi. Selain itu, gangguan aliran pembuluh darah coroner juga dapat terjadi akibat penyumbatan aliran darah pembuluh darah coroner dan apabila tidak ditindaklanjuti, dapat menimbulkan penyakit jantung coroner dan berujung kematian.

Upaya yang perlu dilakukan oleh petugas kesehatan untuk mencegah komplikasi adalah dengan melakukan upaya promotif dan preventif dimana individu diajarkan untuk mengenal tanda dan gejala serta melakukan tindakan-tindakan preventif untuk mengontrol dan mencegah kenaikan tekanan darah yang tidak terkontrol seperti mengelola berat badan, pengaturan menu makanan dengan mengurangi asupan garam secara berlebihan serta rutin melakukan check up tekanan darah. Apabila dengan tindakan promotif serta preventif tekanan darah masih tinggi perlu mengkonsumsi obat antihipertensi sesuai program medik.

\section{METODE}

Alat dan bahan yang digunakan dalam kegiatan pembinaan kesehatan meliputi;.meja kerja 3 buah yang terdiri dari ; meja pendaftaran, meja pemeriksaan kesehatan (tensi, pemeriksaan kolesterol, gula darah) dan meja konsultasi, kursi tunggu, wearless, serta musik pengantar senam,

Rangkaian kegiatan diawali dengan registrasi di bagian meja pendaftaran, selanjutnya menuju meja pemeriksaan dan dilakukan pemeriksaan tekanan darah, pengambilan darah tepi untuk memeriksa gula darah. Bagi Lansia yang hasil pemeriksaannya tinggi dikonsultasikan ke dokter untuk mendapatkan terapi pengobatan. Pada bagian akhir dilaksanakan penyuluhan kesehatan tentang Hipertensi dan mengajarkan para Lansia senam antihipertensi.

\section{HASIL dan PEMBAHASAN}

Kegiatan Pembinaan kesehatan Lansia dilaksanakan di Posyandu Lansia wilayah Puskesmas Pasundan 
Samarinda. Lansia yang hadir berjumlag 28 orang. Kehadiran Lansia serta hasil pemeriksaan disajikan dalam tabel sebagai berikut :

Tabel 1. Alat dan bahan Pembinaan Kesehatan Posyandu Lansia Merapi Wilayah Kerja Puskesmas Pasundan

\begin{tabular}{lll}
\hline No & Alat dan Bahan & n \\
\hline $\mathbf{1}$ & Wearless & 1 \\
$\mathbf{2}$ & Mikrofon & $\mathbf{1}$ \\
$\mathbf{3}$ & Leaflet & $\mathbf{5 0}$ \\
$\mathbf{4}$ & Tensimeter & $\mathbf{2}$ \\
$\mathbf{5}$ & Alat Glukose meter+baterai & $\mathbf{1}$ \\
$\mathbf{6}$ & Unit Lancing Device & $\mathbf{1}$ \\
$\mathbf{7}$ & Test Strip (box) & $\mathbf{1}$ \\
$\mathbf{8}$ & Musik pengantar senam & $\mathbf{1}$ \\
\hline
\end{tabular}

Tabel 2. Distribusi Peserta Posyandu berdasarkan Jenis Kelamin

\begin{tabular}{ccc}
\hline Jenis Kelamin & Jumlah & $\%$ \\
\hline Pria & 3 & 11 \\
Perempuan & 25 & 89 \\
\hline & 28 & 100 \\
\hline
\end{tabular}

Berdasarkan tabel 2 diatas, peserta posyandu yang terbanyak adalah perempuan berjumlah 25 orang dengan prosentase $89 \%$.

Tabel 3. Distribusi Peserta Posyandu Berdasarkan Usia

\begin{tabular}{ccc}
\hline Usia & Jumlah & $\%$ \\
\hline $46-55$ tahun & 13 & 46 \\
$56-65$ tahun & 14 & 50 \\
65 tahun keatas & 1 & 4 \\
& 28 & 100 \\
\hline
\end{tabular}

Berdasarkan tabel 3 diatas, distribusi peserta posyandu berdasarkan usia yang terbanyak rentang usia 56 - 65 tahun berjumlah 14 orang dengan prosentase $50 \%$.

Tabel 4 Distribusi Hasil Pemeriksaan Kesehatan Tekanan Darah Berdasarkan Klasifikasi Hipertensi Menurut JNC7*

\begin{tabular}{lcccc}
\hline Katagori & Sistolik & Diastolik & Jumlah & $\%$ \\
\hline Normal & $<120$ & $<80$ & 9 & 32 \\
\hline $\begin{array}{l}\text { Pre } \\
\text { hipertensi }\end{array}$ & $120-139$ & $80-89$ & 8 & 29 \\
\hline $\begin{array}{l}\text { Hipertensi } \\
\text { Tahap 1 }\end{array}$ & $140-159$ & $90-99$ & 8 & 29 \\
\hline $\begin{array}{l}\text { Hipertensi } \\
\text { Tahap 2 }\end{array}$ & $\geq 160$ & $\geq 100$ & 3 & 10 \\
\hline
\end{tabular}

*JNC7 = Joint National Committe7
Berdasarkan tabel 4 diatas, Distribusi hasil pemeriksaan tekanan darah menurut klasifikasi JNC7 peserta posyandu yang memiliki tekanan darah normal berjumlah 9 orang dengan prosentase 32\%, Prehipertensi berjumlah 8 orang dengan prosentase 29\%, Hipertensi tahap satu 8 orang dengan prosentase $29 \%$ dan Hipertensi tahap dua berjumlah 3 orang dengan prosentase $10 \%$.

Tabel 5. Distribusi Hasil Pemeriksaan Gula Darah

\begin{tabular}{ccc}
\hline Gula Darah & Jumlah & $\%$ \\
\hline $80-120$ & 8 & 29 \\
$>120$ & 20 & 71 \\
\hline & 28 & 100 \\
\hline
\end{tabular}

Berdasarkan tabel 5 diatas, distribusi hasil pemeriksaan gula darah yang hasilnya diatas $120 \mathrm{mg} / \mathrm{dl}$ merupakan yang terbanyak yaitu 20 orang dengan prosentase $71 \%$.

\section{KESIMPULAN}

Penyakit hipertensi merupakan penyakit tidak menular, tetapi merupakan penyakit sebagai akibat dari proses degenerative dan pola hidup yang tidak sehat, dan semakin tahun penyakit ini meningkat dengan resiko komplikasi yang bervariasi dari ringan sampai berat bahkan bisa menyebabkan kematian.

Latihan olahraga secara teratur dapat meningkatkan fungsi tubuh terutama fungsi jantung. Salah satu cara untuk menjaga kesehatan jantung adalah dengan olahraga yang teratur. Olahraga ringan yang mudah dilakukan adalah senam. Senam memiliki banyak manfaat diantaranya adalah melancarkan peredaran darah dan meningkatkan jumlah volume darah. Sehingga dengan melakukan senam 
secara teratur dapat meminimalkan terjadinya penyakit jantung terutama hipertensi pada oang lansia.

\section{UCAPAN TERIMA KASIH}

Kegiatan ini dapat berjalan berkat dukungan dari STIKES Dirgahayu sebagai sponsor utama yang memberi dukungan penuh dalam pembiayaan kegiatan sehingga dapat terlaksana dengan baik dan memberikan manfaat yang sebesarnya bagi masyarakat, khususnya wilayah kerja Puskesmas Pasundan Kelurahan Jawa Samarinda .

\section{SARAN}

1. Peran perawat dalam upaya meningkatkan kesehatan (promotive) dengan memberikan pendidikan kesehatan/penyuluhan perlu ditingkatkan, sehingga masyarakat dan keluarga memahami benar penyakit hipertensi dan bagaimana memodifikasi gaya hidup yang lebih sehat.

2. Perlu dijadwalkan secara rutin olah raga/senam antihipertensi kepada Lansia sebagai salah satu upaya mengontrol tekanan darah disamping konsumsi obat dan pembatasan asupan natrium sehari-hari.

\section{DAFTAR PUSTAKA}

Anggriyana, Tri Widianti (2010). Senam Kesehatan Aplikasi Senam Untuk Kesehatan. Yogyakarta : Nuha Medika. Azizah, lilik ma'rifatul, 2011. Keperawatan lanjut usia. Edisi pertama. Yogyakarta : Graha Ilmu.

Admin. 2010. Lansia Perlukan Dukungan Keluarga dan Masyarakat. http:// www.vivaborneo.com/lansia-perlukandukungan-keluarge-danmasyarakat.htm. Di akses tanggal : 27 juli 2011

Elsanti (2007). Pengelolaan Penyakit Hipertensi. Jakarta : EGC

Dede Kusmana (2006). Olah raga Untuk Orang Sehat dan Penderita Penyakit Jantung. Jakarta : Penerbit fakultas Kedokteran Universitas Indonesia
Kesehatan, B. P. (2013). Riset Kesehatan Dasar. Kementerian Kesehatan RI.

Made Astawan (2013). Cegah Hipertensi dengan Pola Makan. Bandung : Aksara 